\title{
Mosquito larvicidal and silver nanoparticles synthesis potential of plant latex
}

\author{
H.P. Borase, ${ }^{1}$ C.D. Patil, ${ }^{1}$ R.B. Salunkhe, ${ }^{1}$ C.P. Narkhede, ${ }^{1}$ R.K. Suryawanshi, ${ }^{1}$ B.K. Salunke, ${ }^{1}$ \\ S.V. Patil ${ }^{1,2}$ \\ ${ }^{1}$ School of Life Sciences, North Maharashtra University; ${ }^{2}$ North Maharashtra Microbial Culture \\ Collection Centre (NMCC), North Maharashtra University, India
}

\begin{abstract}
Silver nanoparticles (AgNPs) were synthesized from the latex of the medicinally important plants Euphorbia milii, Euphorbia hirta, Ficus racemosa and Jatropha curcas. Synthesized AgNPs were characterized by UV-Vis spectrophotometry, scanning electron microscopy, energy dispersive X-ray analysis, X-ray diffraction, Fourier transformed infrared spectroscopy, particle size, and zeta potential analysis. Potency of latex and latex-synthesized AgNPs was evaluated against the $2^{\text {nd }}$ and $4^{\text {th }}$ instar larvae of Aedes aegypti and Anopheles stephensi. The lowest lethal concentration $50\left(\mathrm{LC}_{50}\right)$ value among the different types of plant latex studied was observed for latex of $E$. milii (281.28 \pm 23.30 and $178.97 \pm 37.82 \mathrm{ppm}$, respectively) against $2^{\text {nd }}$ instar larvae of Ae. aegypti and An. stephensi. E. milii latex-synthesised AgNPs showed a high reduction in $\mathrm{LC}_{50}$ compared with its latex; i.e., $8.76 \pm 0.46$ and $8.67 \pm 0.47 \mathrm{ppm}$, respectively, for $2^{\text {nd }}$ instars of Ae. aegyp$t i$ and An. stephensi. $\mathrm{LC}_{50}$ values of AgNPs synthesized using the latex of $E$. hirta, F. racemosa and J. curcas were lower than those of the latex of the respective plants; i.e., $10.77 \pm 0.53,9.81 \pm 0.52,12.06 \pm 0.60$ and $8.79 \pm 0.51,9.83 \pm 0.52,9.60 \pm 0.51 \mathrm{ppm}$, respectively, for $2^{\text {nd }}$ instars of $A n$. stephensi and Ae. aegypti. Similarly, as compared with the plant latex,
\end{abstract}

Correspondence: Satish V. Patil, School of Life Sciences, North Maharashtra University, Post Box 80, Jalgaon 425001, Maharashtra, India.

Tel.: +91.257.2257421 - Fax: +91.257 .2258403 .

E-mail: satish.patil7@gmail.com

Key words: plant latex, mosquito biolarvicidal, silver nanoparticles, Anopheles stephensi, Aedes aegypti.

Acknowledgements: Hemant P. Borase is DST-INSPIRE fellow (Grant File No. DST/INSPIRE Fellowship/2011[149].), Chandrashekhar D. Patil is thankful to CSIR (Ref: 09/728 (0028)/2012- EMR-I) for the award of senior research fellowship.

Received for publication: 12 September 2013.

Revision received: 26 December 2013.

Accepted for publication: 17 January 2014.

(C) Copyright H.P. Borase et al., 2014

Licensee PAGEPress, Italy

Journal of Entomological and Acarological Research 2014; 46:1920

doi:10.4081/jear.2014.1920

This article is distributed under the terms of the Creative Commons Attribution Noncommercial License (by-nc 3.0) which permits any noncommercial use, distribution, and reproduction in any medium, provided the original author(s) and source are credited. lower $\mathrm{LC}_{50}$ values were reported for latex-synthesized AgNPs against $4^{\text {th }}$ instars of Ae. aegypt and An. stephensi. Results showed that all the types of plant latex investigated have the potential to convert silver nitrate into AgNPs showing a spectrum of potent mosquito larvicidal effects, indicating the possibility of further exploration of the bioefficacy of latex and latex-synthesized AgNPs against vectors of public health concerns.

\section{Introduction}

About 3.3 and 2.5 billion people, respectively, are at risk of malaria and dengue worldwide, with a higher frequency in the population of sub-Saharan Africa (SSA) (WHO, 2009, 2011). In India, 1.49 million cases of malaria, 28,292 cases of dengue, 767 and 108 deaths were reported from malaria and dengue in 2010 (NVBDCP, 2011). The above figures indicate the global impact of mosquito-transmitted diseases with respect to loss of national productivity due to mortality and morbidity. Mosquito species such as Anopheles stephensi, Aedes aegypti and Culex quinquefasciatus are widely distributed in the tropical and subtropical zones, acting as vectors of diseases like malaria, dengue, filariasis, Japanese encephalitis, yellow fever, and chikungunya (WHO, 2009). To control the outbreak of mosquito-borne diseases, attention should be given to targeting the larval stage of mosquitoes, which are unable to fly and are present in the breeding habitat. Devising a control methodology should therefore be relatively easy for the larval stage. During the past several decades, organophosphates such as temephos and fenthion, and insect growth regulators such as diflubenzuron and methoprene, have been used to control mosquito larvae (Yang et al., 2002). Insecticides of microbial origin, such as Bacillus thuringiensis, have also been employed for larval control (Raghvendra et al., 2011). However, continued and indiscriminate use of these insecticides creates problems such as insecticide resistance, environmental pollution and toxicity to human and non-target organisms (Raghvendra et al., 2011). To combat these shortcomings of chemical insecticides, research has shifted toward products of biological origin (Patil et al., 2012a; Karunamoorthi, 2013).

Use of products of plant origin to control mosquito larvae has been shown to be an exciting alternative to traditional methods of larval management, as they are not associated with the problems noted above (Shaalan et al., 2005, Borase et al., 2013). For example, root and leaf extracts of Plumbego zeylanica and Cestrum nocturnum (Patil et al., 2011b), leaf extracts of Ocimum sanctum, Phyllanthus emblica (Murugan et al., 2012), and hydrodistillate extracts of Mentha piperita, Ocimum basilicum, Zingiber officinale, and curcuma longa (Kalaivani et al., 2012) have been used against mosquito larvae of An. stephensi, Ae. aegypti and $\mathrm{Cu}$. quinquefasciatus.

The use of phytosynthesized silver nanoparticles as a larvicidal 
agent instead of chemical insecticides is gaining importance because of their safety to users as well as nontarget species, and the novelty of their mechanism of action (Marimuthu et al., 2011; Patil et al., 2012b). Several plants have been screened successfully for silver nanoparticle synthesis, such as Plumeria rubra. (Patil et al., 2011a), Pergularia daemia (Patil et al., 2012a), Acacia arabica (Thakur et al., 2013), Cadaba indica lam leaf extract (Kalimuthu et al., 2013), Euphorbia tirucalli, and Alstonia macrophylla (Borase et al., 2013), as described in a review by Gan \& Li (2012). Chemical and physical methods of nanosynthesis have shortcomings such as the use of toxic chemicals and high temperatures. To address these, the use of living organisms such as plants and microorganisms (bacteria and fungi) for nanoparticle synthesis is gaining momentum.

Latex is a milky to transparent sap produced in some plants and studied mostly with respect to rubber production, interactions with insects as a plant defense mechanism, and in explorations of different pharmacological activities (Kekwick, 2007). The latex-producing plants $E$. milii, E. hirta, F. racemosa and J. curcas used in the present study are available in large quantities locally in India and have been reported in the literature for their medicinal applications as well as for their active biochemical constituents (Table 1). For these reasons and because of the potent mosquito larvicidal activity showed by plant Plumeria rubra and Pergularia daemia and synthesized AgNPs in our earlier study (Patil et al., 2011a; 2012a), we wanted to investigate the potential of other types of plant latex as eco-friendly mosquito larvicidal agents, and as precursors for environmentally benign silver nanoparticle synthesis.

\section{Materials and methods}

\section{Plant material}

E. milii, E. hirta, F. racemosa and J. curcas growing in the vicinity of Jalgaon, India, were used as sources of fresh latex. Latex was collected in the early morning during March, 2013, by making a small incision near the youngest leaves and at the ends of branches. Extruded latex was collected in sterile tubes $(10 \mathrm{~mL})$. Tubes were kept at $4^{\circ} \mathrm{C}$ to stop coagulation until the time of the experiments.

\section{Phytochemical characterisation of latex}

Latex samples were subjected to qualitative tests for the presence of different metabolites as reported by Kokate (1999) and Patil et al. (2012b).

\section{Synthesis of silver nanoparticles}

One $\mathrm{mL}$ of fresh latex was added to $100 \mathrm{~mL}$ of an aqueous solution of silver nitrate $(100 \mathrm{ppm})$. The flask was incubated on a rotary shaker $\left(28^{\circ} \mathrm{C}\right.$ at $\left.120 \mathrm{rpm}\right)$. Simultaneously, controls containing latex with Milli- $Q$ deionized water and silver nitrate solution alone were maintained under the same conditions. Solutions were observed periodically for any colour change.

\section{Test organisms}

For the laboratory trials, locally collected early $2^{\text {nd }}$ and $4^{\text {th }}$ instar larvae of Ae. aegypti and An. stephensi were used as experimental specimens. The larvae were kept in plastic enamel trays containing dechlorinated tap water, and were maintained as reported by Kalimuthu et al. (2013).

\section{Mosquito larvicidal bioassay}

Different concentrations of latex and AgNPs were prepared in dechlorinated tap water. Larvicidal activity was assessed using the procedure of WHO (1996) with some modifications and as per the methods of Patil et al. (2011b, 2012b). Twenty five $2^{\text {nd }}$ and $4^{\text {th }}$ instar larvae were taken in four batches in $249 \mathrm{~mL}$ of water, and $1.0 \mathrm{~mL}$ of the desired concentration of latex plus AgNPs were added. The control was set up with dechlorinated tap water. The numbers of dead larvae were counted after $24 \mathrm{~h}$ of exposure, and the percent mortality was recorded for the average of four replicates. The experimental media, in which $100 \%$ mortality of larvae occurred, was selected for the dose-response bioassay (data not shown).

\section{Dose response bioassay}

Based on the preliminary screening results, crude latex extract of the experimental plants plus synthesized AgNPs were subjected to a dose-response bioassay for larvicidal activity against the larvae of $A e$. aegypti and An. stephensi. Different concentrations ranging from 62.25

Table 1. Medicinal properties and chemical constituents of latex producing plants used for analysing larvicidal and silver nanoparticle synthesis potential.

\begin{tabular}{|c|c|c|c|c|c|}
\hline Botanical name & $\begin{array}{l}\text { Common name } \\
\text { (vernacular name) }\end{array}$ & Family & $\begin{array}{l}\text { Medicinal } \\
\text { property }\end{array}$ & $\begin{array}{l}\text { Chemical } \\
\text { constituents }\end{array}$ & References \\
\hline Euphorbia milii & $\begin{array}{l}\text { Milli Crown of throrn } \\
\text { (Christ Plant) }\end{array}$ & Euphorbiaceae & Molluscicidal & $\begin{array}{l}\text { Miliin, serine proteas, } \\
\text { flavons, triterpenoids, } \\
\text { steroids, steroidal glycoside, } \\
\text { alkaloids }\end{array}$ & Yadav et al. (2006); \\
\hline Euphorbia hirta & $\begin{array}{l}\text { Tawa-tawa } \\
\text { (Dudhi) }\end{array}$ & Euphorbiaceae & $\begin{array}{l}\text { Antihelminthic, } \\
\text { repellent, antifeedant } \\
\text { and controlling Plutella } \\
\text { xylostella and nematicidal } \\
\text { and against roundworm } \\
\text { like guinea worm }\end{array}$ & $\begin{array}{l}\text { Sterols, alkaloids, tannins, } \\
\text { glycosides, triterpenoids, } \\
\text { alkenes, phenolic acids, } \\
\text { choline and shikimic acid }\end{array}$ & $\begin{array}{c}\text { Iwu (1993); } \\
\text { Wei et al. (2005); } \\
\text { Kumar et al. (2002); } \\
\text { Parekh \& Chanda (2007); } \\
\text { Rajeh et al. (2012) }\end{array}$ \\
\hline Ficus racemosa & $\begin{array}{l}\text { Cluster Fig Tree } \\
\text { (Udumbara) }\end{array}$ & Moraceae & $\begin{array}{l}\text { Anti-inflammatory, } \\
\text { antidiarrheal, clears horsevoice } \\
\text { and chemomodulatory, larvicides }\end{array}$ & $\begin{array}{l}\text { Racemosic acid, } \\
\text { triterpenes }\end{array}$ & $\begin{array}{l}\text { Khan \& Sultana (2005); } \\
\quad \text { Li et al. (2004); } \\
\text { Rahuman et al. (2008) }\end{array}$ \\
\hline Jatropha curcus & $\begin{array}{l}\text { Bagbherenda } \\
\text { (Jungli erand) }\end{array}$ & Euphorbiaceae & $\begin{array}{l}\text { Nematicidal, fungicidal, } \\
\text { mosquito (Ochlerototatus } \\
\text { triseriatus) larvicidal, } \\
\text { insecticidal activities }\end{array}$ & $\begin{array}{l}\text { Triglycerols, sterols, } \\
\text { oils, phorbal esters, } \\
\text { glucanase protein }\end{array}$ & $\begin{array}{l}\text { Sharma \& Trivedi (2002); } \\
\text { Gübitz et al. (1999) }\end{array}$ \\
\hline
\end{tabular}


to $2000 \mathrm{ppm}$ (for the latex) and 0.625 to $20 \mathrm{ppm}$ (for the synthesized AgNPs) were prepared, and numbers of dead larvae were counted after $24 \mathrm{~h}$ of exposure; percent mortality was reported from the average of four replicates.

\section{Statistical analysis}

Mortality was calculated using Abbott's formula (Abbott, 1925). The dose-response data were subjected to probit regression analysis (Finney, 1971). The lethal concentrations in parts per million $\left(\mathrm{LC}_{50}\right.$, $\mathrm{LC}_{90}$ ) and the $95 \%$ confidence intervals of $\mathrm{LC}_{50}$ (upper confidence limit) and (lower confidence limit) were calculated.

\section{Characterisation of silver nanoparticles}

AgNPs solutions were centrifuged at 10,000 rpm for 10 min (REMI, Cooling centrifuge, C-24 BL, India); the pellet obtained was resuspended in water and used to analyse surface plasmon resonance of the silver nanoparticles using a UV-Vis spectrophotometer (Shimadzu 1601, Tokyo, Japan) at the resolution of $1 \mathrm{~nm}$ from 200 to $800 \mathrm{~nm}$. Other techniques used for AgNPs characterization included Fourier-transformed infrared spectroscopy (FT-IR) (Shimadzu, Prestige 21, Tokyo, Japan), scanning electron microscopy (SEM), energy dispersive X-ray (EDX) (HITACHI- S4800, Tokyo, Japan), X-ray diffraction (XRD) (Brucker D8 Advance, Karlsruhe, Germany), particle size, and zeta potential analysis (Zetasizer, Malvern Instrument Ltd, Westborough, MA, USA).

\section{Results}

\section{Synthesis and characterisation of AgNPs}

Transformations of $\mathrm{AgNO}_{3}$ to AgNPs were clearly indicated by a colour change of $\mathrm{AgNO}_{3}$ from colourless to yellowish brown, depleting all the plant latex within 5 to 20 min of latex addition, without agglomeration and indicating synthesis of stable AgNPs (Figure 1A). Latex of $E$. milii showed the fastest colour change among all types of latex tested (within
5 min). Synthesized nanoparticles were characterized by UV-Visible spectroscopy showing a surface plasmon resonance band at 410 to 450 $\mathrm{nm}$, which arises due to the conduction of free electrons on the surface of AgNPs (Figure 1B) (Smitha et al., 2008). Absorption maxima at 440, 433,419 , and $444 \mathrm{~nm}$ were observed for AgNPs synthesized from $E$. milii, E. hirta, F. racemosa and J. curcas, respectively. Similar results have been shown by Borase et al. (2013) and Thakur et al. (2013). Absorbance of AgNPs synthesized from the latex of $E$. milii was found to be higher than the other types of plant latex under study. E. milii latex-fabricated AgNPs show a smaller size of $208 \mathrm{~nm}$ with a zeta potential of $-9.19 \mathrm{mV}$ (Figure
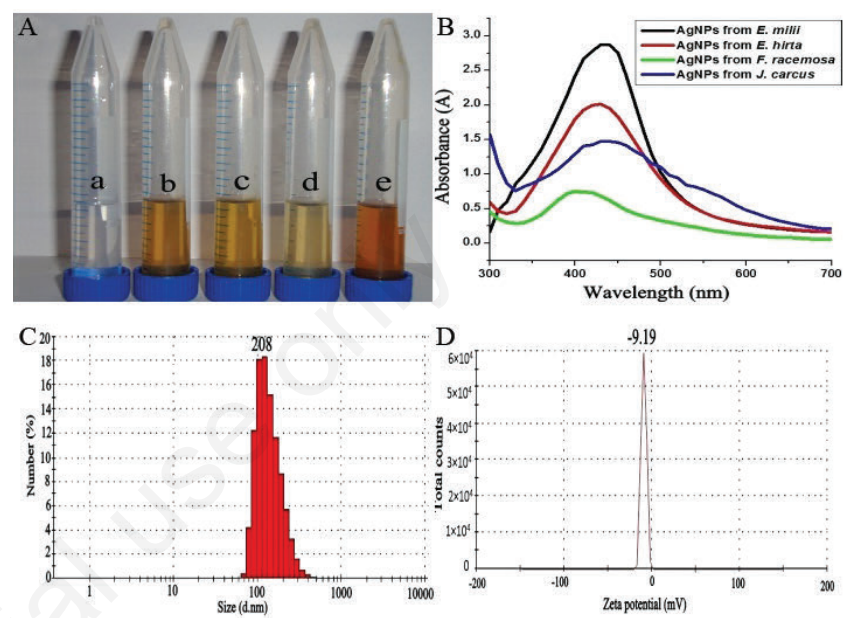

Figure 1. A) Tubes showing colour change of AgNPs: a. silver nitrate solution, b. E. milii, c. E. hirta, d. F. Racemosa, and e. J. curcas. B) UV spectra of AgNPs. C and D) Particle size and zeta potential analysis of AgNPs produced from $E$. milii latex.
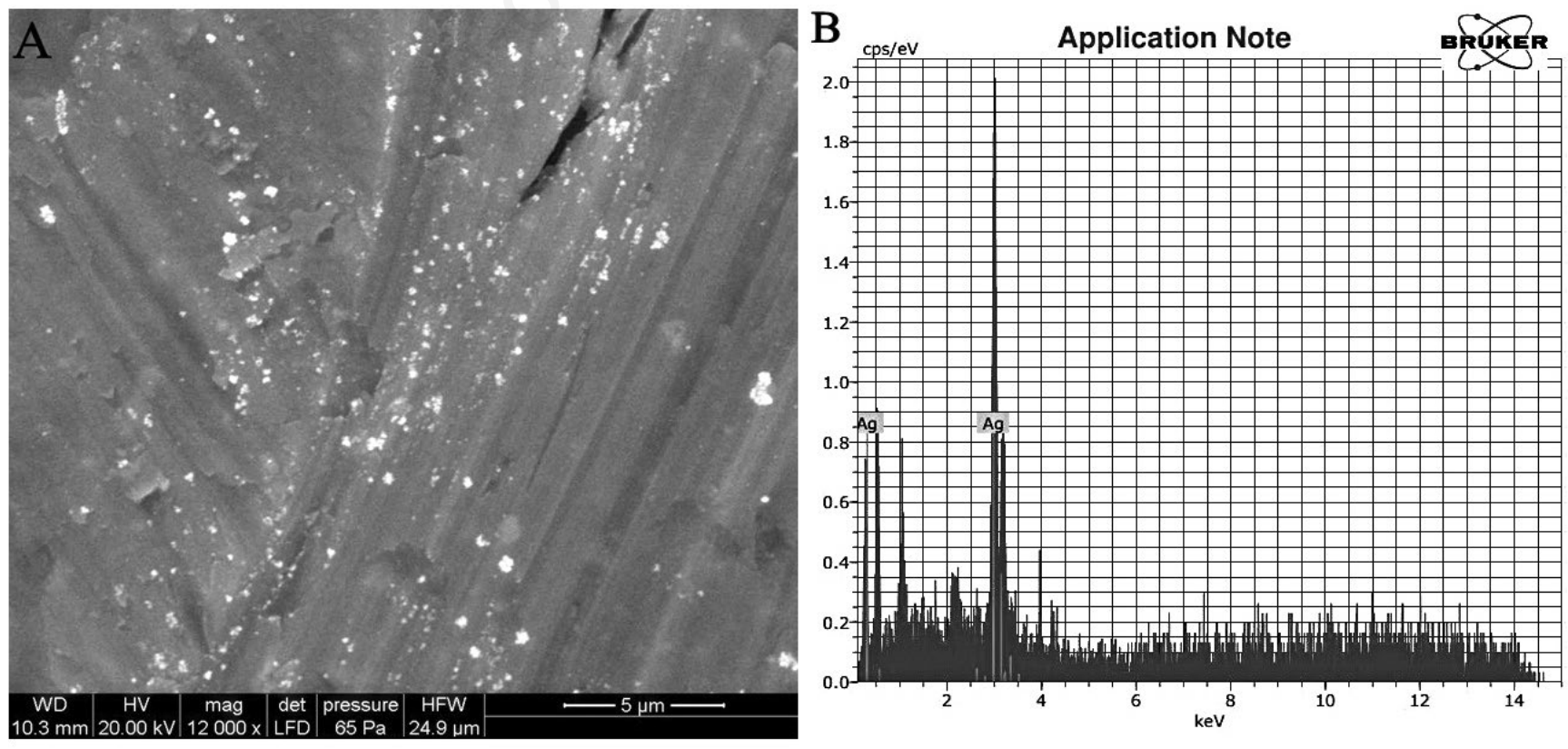

Figure 2. A and B) Scanning electron microscopy and energy dispersive X-ray image of AgNPs synthesized from $E$. milii. 
1C and D). AgNPs from E. hirta, F. racemosa and J. curcas showed larger size particles having low stability, as compared with $E$. milii-synthesized AgNPs (data not shown). SEM imaging showed high density of spherical size, monodispersed AgNPs (Figure 2A). EDX spectra confirmed the presence of elemental silver in the samples, as there was a strong signal for the silver atom (Figure 2B).

Fourier transformed infrared spectroscopy analysis showed the presence of different functional groups corresponding to proteins, alkaloids, tannins, saponins and other plant metabolites (Figure 3A). A peak at $670.03 \mathrm{~cm}^{-1}$ was assigned to $\mathrm{N}-\mathrm{H}$ wag of amines of proteins, $701.91 \mathrm{~cm}^{-1}$ as a C-H deformation in carbohydrates, $3439.96 \mathrm{~cm}^{-1}$ for Ar$\mathrm{OH}, \mathrm{O}-\mathrm{H}$ and $\mathrm{N}-\mathrm{H}$ for phenols, alcohols and amides, and $2997.48 \mathrm{~cm}^{-1}$ for the $\mathrm{C}=\mathrm{O}$ bond found in terpenoids and flavonoids. The remaining peaks also indicate the presence of proteins, flavonoids, saponins and other plant metabolites, as evidenced by qualitative phytochemical analysis (Table 2). XRD analysis revealed the crystalline nature of AgNPs. Other peaks in the XRD may arise due to biomolecules capped on the AgNPs surface (Figure 3B).

\section{Mosquito larvicidal bioassay}

The plant latex under study and AgNPs fabricated from the latex were used to analyse their potency against the $2^{\text {nd }}$ and $4^{\text {th }}$ instar larvae of $A e$. aegypti and An. stephensi. The results of larvicidal bioassays of the plant latex are presented in Tables 3 and 4, and that of the plant latex-synthesized AgNPs are presented in Tables 5 and 6. All tested plant latex and synthesized AgNPs showed larvicidal efficacy within $24 \mathrm{~h}$ of exposure. Mortality rate $(\mathrm{Y})$ was positively related to the dose $(\mathrm{X})$, indicating that mortality is dose-dependent. Latex materials from all the plants tested were less toxic than the synthesized AgNPs to both mosquito species.

Among the AgNPs tested, the AgNPs synthesized from the latex of $E$. milii were highly effective against $A n$. stephensi $\left(\mathrm{LC}_{50}=8.76 \mathrm{ppm}, \mathrm{LC}_{90}=\right.$ $17.11 \mathrm{ppm}$ ), and the AgNPs from J. curcas was highly effective against Ae. Aegypti $\left(\mathrm{LC}_{50}=9.43 \mathrm{ppm}, \mathrm{LC}_{90}=18.20 \mathrm{ppm}\right)$. All the plants used in the present study showed $\mathrm{LC}_{50}$ values less than $13 \mathrm{ppm}$, which could be an important factor in determining a practical larvicidal dose.

\section{Discussion}

Latex producing plants secrete milky fluid from a network of laticifer cells, in which subcellular organelles intensively synthesize proteins and secondary metabolites (Lopes et al., 2009). The biological importance of latex fluids is still unclear and knowledge of their physiological role is still limited (Ramos et al., 2007). Ramos et al. (2009) presented first evidence for the use of Calotropis procerra (Ait.) R.Br.-secreted proteolytic enzymes as chemical agents against Ae. aegypti larvae. Plant latex has been reported to have a negative effect on several insect functions such as egg hatch, larval growth and survival (Giridhar et al., 1984; Morsy et al., 2001; Ramos et al., 2006). The chemico-physical method of nanoparticle synthesis involves the use of toxic substances (sodium borohydrate, polyvinylpyrrolidone) that are harmful to the environment. Our method of AgNPs synthesis using latex, which has an abundance of proteins, enzymes and secondary metabolites, is novel, eco-friendly, and does not require toxic chemicals. Previous studies have demonstrated the involvement of proteins, polyphenols and carbohydrates in the synthesis of
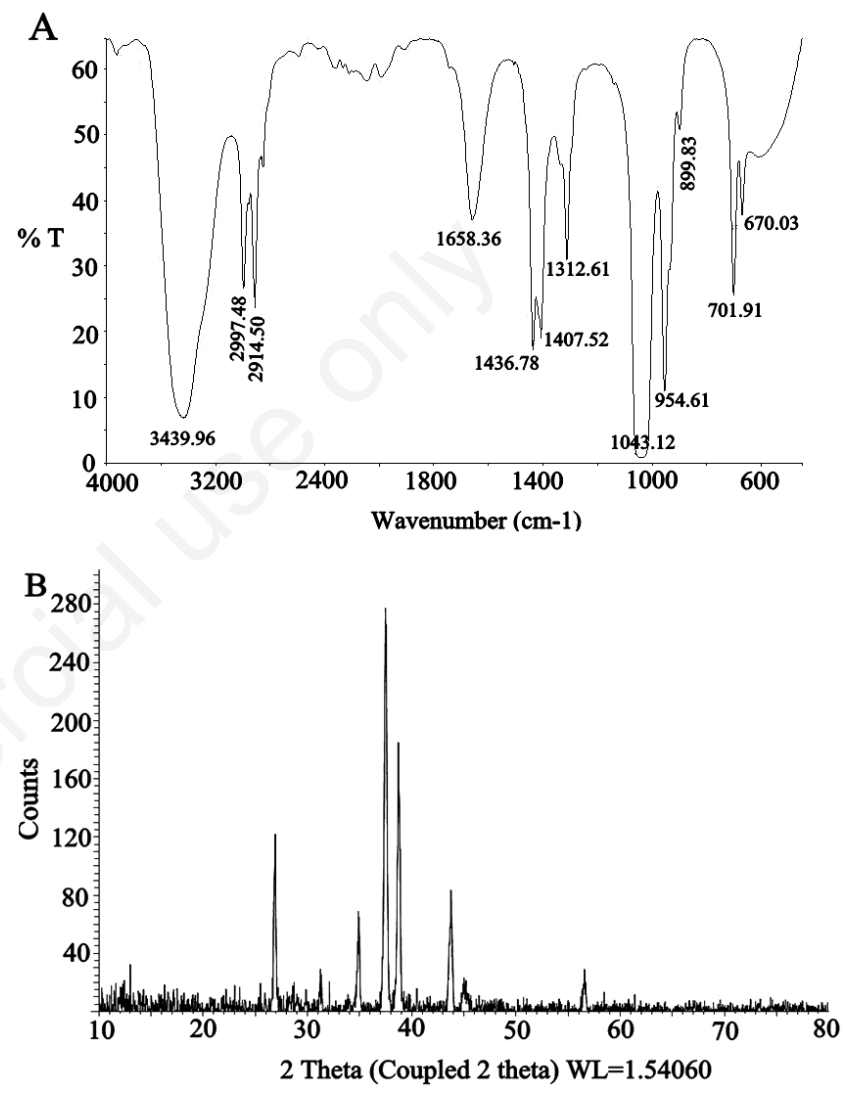

Figure 3. A and B) Fourier transformed infrared spectroscopy and $\mathrm{X}$-ray diffraction spectrum of AgNPs synthesized from $E$. milii.

Table 2. Phytochemical analysis of plant latex.

\begin{tabular}{|c|c|c|c|c|c|}
\hline Sr. No. & Metabolites & E. milit & E. hirta & F. racemosa & J. curcas \\
\hline 1 & Protein & + & + & + & + \\
\hline 2 & Carbohydrates & + & - & + & - \\
\hline 3 & Terpenoids & + & + & + & + \\
\hline 4 & Alkaloids & - & + & + & + \\
\hline 5 & Phenolics & + & + & + & + \\
\hline 6 & Flavonoids & + & + & + & + \\
\hline 7 & Tannin & + & + & - & - \\
\hline 8 & Saponins & + & + & + & + \\
\hline 9 & Glycosides & + & - & + & - \\
\hline
\end{tabular}

$+=$ present; $-=$ absent. Sr., serial number. 
metal nanoparticles (Gan \& Li, 2012). Nanoparticles produced using chemical methods are of a defined size and shape due to the use of a single reducing and capping agent. In biological synthesis, diverse particle size and shape is observed because of multiple reducing and capping agents. Consequently, isolation, purification and scale-up of compounds responsible for nanoconversion of silver represent potentially valuable alternatives to chemical synthesis.

Duran et al. (2011) discussed involvement of the enzyme NADPHdependent nitrate reductase in production of AgNPs, while Vigneshwaran et al. (2006) showed the role of reducing sugars in AgNPs production, AgNPs synthesis were also reported from combination of reducing agents and terpenoids (Shankar et al., 2004), polyols, eugenol, quinines and Phyllanthin (Jha et al., 2009; Kasthuri et al., 2009; Singh et al., 2010). The plant latex used in the present study also showed the presence of proteins and secondary metabolites (terpenoids, tannins, alkaloids and others), so we may preliminarily conclude there is an interaction of enzymatic and non-enzymatic compounds in AgNPs formation.

Corbel et al. (2007) showed that increased insecticide resistance in mosquitoes is due to increased activity of enzymes involved in insecticide metabolism (e.g., esterases, oxidases, glutathione-S-transferase) and mutation in the target sites of insecticide action. This can be corroborated with how AgNPs exhibit their larvicidal action. AgNPs have a high surface area-to-volume ratio, which imparts to them many types of biocidal and catalytic activities. Also, in latex-mediated nanosynthesis, capping of latex metabolites on the surface of the AgNPs, in addition to imparting stability, also increases their larvicidal action. The higher mortality at lower doses is consistent with earlier reports of AgNPs produced from leaf extracts of Nelumbo nucifera $\left(\mathrm{LC}_{50}=0.69\right.$ ppm, $\mathrm{LC}_{90}=2.15 \mathrm{ppm}$ ) against An. subpictus and $\mathrm{Cu}$. quinquefasciatus $\left(\mathrm{LC}_{50}=1.10 \mathrm{ppm}, \mathrm{LC}_{90}=3.59 \mathrm{ppm}\right)$ Thirunavukkarasu et al. (2010). Marimuthu et al. (2011) reported bioactivity of Mimosa pudica-synthe- sized AgNPs against the larvae of An. subpictus, $C u$. quinquefasciatus, and R. microplus $\left(\mathrm{LC}_{50}=13.90,11.73\right.$ and $\left.8.98 \mathrm{ppm}\right)$, respectively. AgNPs synthesized using Tinospora cordifolia extract were tested against the larvae of An. subpictus $\left(\mathrm{LC}_{50}=6.43 \mathrm{mg} / \mathrm{L}\right)$ and $\mathrm{Cu}$. quinquefasciatus $\left(\mathrm{LC}_{50}=6.96 \mathrm{mg} / \mathrm{L}\right)$ (Jayaseelan et al., 2011).

Shaalan et al. (2005) reported that varying results obtained in lethal concentration values can be due to differences in the levels of toxicity among the insecticidal components of different plants, and the effect of plant extracts can vary significantly depending on plant species, plant part, age of the plant part, extraction solvent, seasonal variation, and mosquito species

In prokaryotic systems, AgNPs have multiple targets for biocidal effects by causing structural damage (Kim et al., 2007), generation of reactive oxygen species, interfering with DNA replication, and reacting with the thiol enzyme group (Liau et al., 1997; Feng et al., 2000). Patil et al. (2012b) also pointed out the antagonistic effect of AgNPs on enzymes and proteins regardless of the Gram characteristics in bacteria. The mechanism of larvicidal action of silver nanoparticles requires more detailed study.

\section{Conclusions}

Studies were conducted to evaluate the potential mosquito larvicidal activity of plant latex and latex-synthesized AgNPs. Our results suggest the possibility of addressing the problem of emerging mosquito resistance to chemical insecticides by using latex, latex-synthesized AgNPs, or combinations of chemical insecticides with latex and AgNPs, which could be considered an alternative larval eradication tactic that could help reduce the burden of toxic chemical insecticides on the environment and non-target organisms.

Table 3. Larvicidal activity of latex against $2^{\text {nd }}$ instars larvae of Aedes aegypti and Anopheles stephensi.

\begin{tabular}{|c|c|c|c|c|c|c|}
\hline Mosquito species & Plant latex & $\begin{array}{l}\mathrm{LC}_{50} \pm \mathrm{SE} \\
\left(\mathrm{mg} \mathrm{L} \mathrm{L}^{-1}\right)\end{array}$ & $\begin{array}{l}\text { 95\% fiducial limits } \\
\text { (LCL-UCL) }\end{array}$ & $\begin{array}{l}\mathrm{LC}_{90} \pm \mathrm{SE} \\
\left(\mathrm{mg} \mathrm{L} \mathrm{L}^{-1}\right)\end{array}$ & $\begin{array}{l}95 \% \text { fiducial limits } \\
\text { (LCL-UCL) }\end{array}$ & $\begin{array}{l}\text { Regression } \\
\text { equation }\end{array}$ \\
\hline Aedes aegypti & $\begin{array}{l}\text { E. milii } \\
\text { E. hirta } \\
\text { F. racemosa } \\
\text { J. carcus }\end{array}$ & $\begin{array}{l}281.28 \pm 23.30 \\
675.26 \pm 39.73 \\
726.69 \pm 42.33 \\
746.98 \pm 48.52\end{array}$ & $\begin{array}{l}234.87-327.91 \\
601.94-760.27 \\
647.66-815.91 \\
655.56-848.55\end{array}$ & $\begin{array}{c}752.27 \pm 51.56 \\
1422.69 \pm 88.19 \\
1555.16 \pm 90.48 \\
1768.99 \pm 109.92\end{array}$ & $\begin{array}{c}665.59-874.59 \\
1272.29-1626.91 \\
1399.16-1761.71 \\
1580.74-2022.16\end{array}$ & $\begin{array}{c}\mathrm{Y}=9.58+0.00941 \mathrm{X} \\
\mathrm{Y}=33.63+0.0112 \mathrm{X} \\
\mathrm{Y}=3.49+0.0111 \mathrm{X} \\
\mathrm{Y}=4.49+0.00993 \mathrm{X}\end{array}$ \\
\hline Anopheles stephensi & $\begin{array}{l}\text { E. milii } \\
\text { F. racemosa } \\
\text { E. hirta } \\
\text { J. carcus }\end{array}$ & $\begin{array}{l}178.97 \pm 37.82 \\
549.52 \pm 54.24 \\
568.74 \pm 46.84 \\
755.70 \pm 49.04 \\
\end{array}$ & $\begin{array}{c}95.93-248.31 \\
441.85-658.39 \\
477.61-664.21 \\
294.70-391.19 \\
\end{array}$ & $\begin{array}{c}909.88 \pm 73.06 \\
1809.71 \pm 134.66 \\
1621.64 \pm 111.01 \\
1772.58 \pm 112.93\end{array}$ & $\begin{array}{c}788.93-1087.58 \\
1584.20-2130.08 \\
1433.66-1881.56 \\
1579.869-2033.902\end{array}$ & $\begin{array}{l}Y=11.9+0.00772 X \\
Y=7.62+0.00820 X \\
Y=6.70+0.00916 X \\
Y=4.37+0.00985 X\end{array}$ \\
\hline
\end{tabular}

$\mathrm{LC}_{50}$, 50\% lethal concentration; SE, standard error; LCL, lower confidence limit; UCL, upper confidence limit; $\mathrm{LC}_{90}, 90 \%$ lethal concentration.

Table 4. Larvicidal activity of latex against $4^{\text {th }}$ instars larvae of Aedes aegypti and Anopheles stephensi.

\begin{tabular}{|c|c|c|c|c|c|c|}
\hline Mosquito species & Plant latex & $\begin{array}{l}\mathrm{LC}_{50} \pm \mathrm{SE} \\
\left(\mathrm{mg} \mathrm{L}^{-1}\right)\end{array}$ & $\begin{array}{l}95 \% \text { fiducial limits } \\
\text { (LCL-UCL) }\end{array}$ & $\begin{array}{l}\mathrm{LC}_{90} \pm \mathrm{SE} \\
\left(\mathrm{mg} \mathrm{L}^{-1}\right)\end{array}$ & $\begin{array}{l}\text { 95\% fiducial limits } \\
\text { (LCL-UCL) }\end{array}$ & $\begin{array}{l}\text { Regression } \\
\text { equation }\end{array}$ \\
\hline Aedes aegypti & $\begin{array}{l}\text { E. milii } \\
\text { E. hirta } \\
\text { F. racemosa } \\
\text { J. carcus }\end{array}$ & $\begin{array}{l}638.11 \pm 36.53 \\
683.69 \pm 39.32 \\
777.43 \pm 43.49 \\
798.89 \pm 46.00\end{array}$ & $\begin{array}{l}571.00-716.69 \\
611.31-768.07 \\
697.64-870.85 \\
713.78-896.79\end{array}$ & $\begin{array}{l}1299.02 \pm 80.07 \\
1408.23 \pm 86.27 \\
1563.74 \pm 93.01 \\
1678.54 \pm 99.45\end{array}$ & $\begin{array}{l}1162.58-1484.72 \\
1260.96-1607.78 \\
1404.19-1777.41 \\
1507.56-1906.32\end{array}$ & $\begin{array}{l}Y=3.45+0.0116 \mathrm{X} \\
Y=3.33+0.0114 \mathrm{X} \\
\mathrm{Y}=2.55+0.0113 \mathrm{X} \\
\mathrm{Y}=3.00+0.0108 \mathrm{X}\end{array}$ \\
\hline Anopheles stephensi & $\begin{array}{l}\text { E. milii } \\
\text { E. hirta } \\
\text { F. racemosa } \\
\text { J. carcus }\end{array}$ & $\begin{array}{l}761.11 \pm 43.43 \\
783.42 \pm 42.89 \\
884.69 \pm 45.65 \\
919.31 \pm 52.52\end{array}$ & $\begin{array}{c}680.80-853.64 \\
704.43-875.06 \\
800.79-982.26 \\
822.32-1031.26\end{array}$ & $\begin{array}{c}1580.75 \pm 93.51 \\
1560.04 \pm 89.73 \\
1681.22 \pm 92.00 \\
1930.60 \pm 113.96\end{array}$ & $\begin{array}{l}1420.08-1795.11 \\
1405.42-1764.95 \\
1521.86-1889.82 \\
1734.54-2191.33\end{array}$ & $\begin{array}{l}Y=3.02+0.0111 \mathrm{X} \\
Y=2.38+0.0115 \mathrm{X} \\
\mathrm{Y}=1.43+0.0115 \mathrm{X} \\
\mathrm{Y}=2.68+0.010 \mathrm{X}\end{array}$ \\
\hline
\end{tabular}

$\mathrm{LC}_{50}, 50 \%$ lethal concentration; SE, standard error; LCL, lower confidence limit; UCL, upper confidence limit; $\mathrm{LC}_{90}, 90 \%$ lethal concentration. 
Table 5. Larvicidal activity of latex synthesized AgNPs against $2^{\text {nd }}$ instars of Aedes aegypti and Anopheles stephensi.

\begin{tabular}{|c|c|c|c|c|c|c|}
\hline Mosquito species & Plant AgNPs & $\begin{array}{l}\mathrm{LC}_{50 \pm \mathrm{SE}} \\
\left(\mathrm{mg} \mathrm{L^{-1 }}\right)\end{array}$ & $\begin{array}{l}95 \% \text { fiducial limits } \\
\text { (LCL-UCL) }\end{array}$ & $\begin{array}{l}\mathrm{LC}_{90} \pm \mathrm{SE} \\
\left(\mathrm{mg} \mathrm{L}^{-1}\right)\end{array}$ & $\begin{array}{l}\text { 95\% fiducial limits } \\
\text { (LCL-UCL) }\end{array}$ & $\begin{array}{l}\text { Regression } \\
\text { equation }\end{array}$ \\
\hline Anopheles stephensi & $\begin{array}{l}\text { E. milii } \\
\text { E. hirta } \\
\text { F. racemosa } \\
\text { J. carcus }\end{array}$ & $\begin{array}{c}8.76 \pm 0.46 \\
10.77 \pm 0.53 \\
9.81 \pm 0.52 \\
12.06 \pm 0.60\end{array}$ & $\begin{array}{c}7.91-9.74 \\
9.78-11.91 \\
8.85-10.93 \\
10.97-13.36\end{array}$ & $\begin{array}{l}17.11 \pm 0.94 \\
20.11 \pm 1.06 \\
19.34 \pm 1.07 \\
22.00 \pm 1.19\end{array}$ & $\begin{array}{c}15.48-19.24 \\
18.27-22.5 \\
17.47-21.78 \\
19.94-24.71\end{array}$ & $\begin{array}{l}Y=1.82+1.13 \mathrm{X} \\
\mathrm{Y}=0.84+1.07 \mathrm{X} \\
\mathrm{Y}=1.69+1.06 \mathrm{X} \\
\mathrm{Y}=0.36+1.01 \mathrm{X}\end{array}$ \\
\hline Aedes aegypti & $\begin{array}{l}\text { E. milii } \\
\text { E. hirta } \\
\text { F. racemosa } \\
\text { J. carcus }\end{array}$ & $\begin{array}{l}8.67 \pm 0.47 \\
8.79 \pm 0.51 \\
9.83 \pm 0.52 \\
9.60 \pm 0.51\end{array}$ & $\begin{array}{c}7.81-9.68 \\
7.82-9.87 \\
8.88-10.93 \\
8.67-10.69\end{array}$ & $\begin{array}{l}17.62 \pm 1.01 \\
19.51 \pm 1.17 \\
19.14 \pm 1.06 \\
18.96 \pm 1.05\end{array}$ & $\begin{array}{l}15.89-19.92 \\
17.50-22.18 \\
17.31-21.54 \\
17.14-21.35\end{array}$ & $\begin{array}{l}Y=2.04+1.11 \mathrm{X} \\
Y=3.21+1.01 \mathrm{X} \\
\mathrm{Y}=1.53+1.07 \mathrm{X} \\
\mathrm{Y}=1.81+1.07 \mathrm{X}\end{array}$ \\
\hline
\end{tabular}

$\mathrm{LC}_{50}, 50 \%$ lethal concentration; SE, standard error; LCL, lower confidence limit; UCL, upper confidence limit; $\mathrm{LC}_{90}, 90 \%$ lethal concentration.

Table 6. Larvicidal activity of latex synthesized AgNPs against larvae of $4^{\text {th }}$ instars of Aedes aegypti and Anopheles stephensi.

\begin{tabular}{|c|c|c|c|c|c|c|}
\hline Mosquito species & Plant AgNPs & $\begin{array}{l}\mathrm{LC}_{50 \pm \mathrm{SE}} \\
\left(\mathrm{mg} \mathrm{L}^{-1}\right)\end{array}$ & $\begin{array}{l}95 \% \text { fiducial limits } \\
\text { (LCL-UCL) }\end{array}$ & $\begin{array}{l}\mathrm{LC}_{90} \pm \mathrm{SE} \\
\left(\mathrm{mg} \mathrm{L}^{-1}\right)\end{array}$ & $\begin{array}{l}95 \% \text { fiducial limits } \\
\text { (LCL-UCL) }\end{array}$ & $\begin{array}{l}\text { Regression } \\
\text { equation }\end{array}$ \\
\hline Aedes aegypti & $\begin{array}{l}\text { J. carcus } \\
\text { E. milii } \\
\text { E. hirta } \\
\text { F. racemosa }\end{array}$ & $\begin{array}{c}9.43 \pm 0.48 \\
9.49 \pm 0.48 \\
10.67 \pm 0.54 \\
11.44 \pm 0.65\end{array}$ & $\begin{array}{c}8.53-10.46 \\
8.61-10.53 \\
9.57-11.85 \\
10.26-12.86\end{array}$ & $\begin{array}{l}18.20 \pm 0.97 \\
17.60 \pm 0.96 \\
20.00 \pm 1.10 \\
23.07 \pm 1.43\end{array}$ & $\begin{array}{l}16.50-20.41 \\
15.93-19.79 \\
18.08-22.51 \\
20.63-26.38\end{array}$ & $\begin{array}{l}Y=9.08+0.009 X \\
Y=0.884+1.14 X \\
Y=0.808+1.06 X \\
Y=1.89+0.925 X\end{array}$ \\
\hline Anopheles stephensi & $\begin{array}{l}\text { E. milii } \\
\text { J. carcus } \\
\text { F. racemosa } \\
\text { E. hirta }\end{array}$ & $\begin{array}{c}9.95 \pm 0.49 \\
10.01 \pm 0.51 \\
11.76 \pm 0.60 \\
12.63 \pm 0.66\end{array}$ & $\begin{array}{c}9.05-11.02 \\
9.07-1.10 \\
10.66-13.7 \\
11.44-14.07\end{array}$ & $\begin{array}{l}18.13 \pm 0.97 \\
19.01 \pm 1.02 \\
21.98 \pm 1.22 \\
23.39 \pm 1.35\end{array}$ & $\begin{array}{l}16.45-20.33 \\
17.24-21.33 \\
19.86-24.77 \\
21.07-26.49\end{array}$ & $\begin{array}{c}Y=0.515+1.14 \mathrm{X} \\
\mathrm{Y}=1.13+1.10 \mathrm{X} \\
\mathrm{Y}=0.723+1.00 \mathrm{X} \\
\mathrm{Y}=0.525+0.95 \mathrm{X}\end{array}$ \\
\hline
\end{tabular}

$\mathrm{LC}_{50}, 50 \%$ lethal concentration; $\mathrm{SE}$, standard error; $\mathrm{LCL}$, lower confidence limit; $\mathrm{UCL}$, upper confidence limit; $\mathrm{LC}_{90}, 90 \%$ lethal concentration.

\section{References}

ABBOTT W.S., 1925 - A method of computing the effectiveness of an insecticide. - J. Ecol. Entomol. 18: 265-266.

BORASE H.P., PATIL C.D., SALUNKHE R.B., NARKHEDE C.P., SALUNKE B.K., PATIL S.V., 2013 - Phyto-synthesized silver nanoparticles: a potent mosquito biolarvicidal agent. - J. Nanomed. Biother. Discov. 3: 1-7.

CORBEL V., GUESSAN R.N., BRENGUES C., CHANDRE F., DJOGBENOU L., MARTIN T., AKOGBETO M., HOUGARD J.M., ROWLAND M., 2007 - Multiple insecticide resistance mechanisms in Anopheles gambiae and Culex quinquefasciatus from Benin, West Africa. - Acta Tropica 101: 207-216.

DURAN N., MARCATO P.D., DURAN M., YADAV A., GADE A., RAI M., 2011 - Mechanistic aspects in the biogenic synthesis of extracellular metal nanoparticles by peptides, bacteria, fungi and plants. Appl. Microbiol. Biotechnol. 90: 1609-1624.

FENG Q.L., WU J., CHEN G.Q., CUI F.Z., KIM T.N., KIM J.O., 2000 - A mechanistic study of the antibacterial effect of silver ions on Escherichia coli and Staphylococcus aureus. - J. Biomed. Mater. Res. 52: 662-668.

FINNEY D.J., 1971 - Probit analysis. - Cambridge University Press, Cambridge: 76-80.

GAN P.P, LI S.F.Y., 2012- Potential of plant as biological factory to synthesize gold and silver nanoparticles and there applications. - Rev. Environ. Sci. Biotechnol. 11:169-206.

GIRIDHAR G., DEVAL K., MITTAL P.K., VASUDEVAN P., 1984 - Mosquito control by Calotropis procera latex. - Pesticides 18: 26-9.

GÜBITZ G.M., MITTELBACH M., TRABI M., 1999 - Exploitation of the tropical oil seed plant Jatropha curcas L. Bioresour. Technol. 67: 73-82.
IWU M.M., 1993 - Handbook of African medicinal plants. - CRC Press, Boca Raton, FL: 24-33.

JAYASEELAN C., RAHUMAN A.A., RAJAKUMAR G., VISHNU KIRTHI A., SANTHOSHKUMAR T., MARIMUTHU S., BAGAVAN A., KAMARAJ C., ZAHIR A.A., ELANGO G., 2011 - Synthesis of pediculocidal and larvicidal silver nanoparticles by leaf extract from heartleaf moonseed plant, Tinospora cordifolia Miers. - Parasitol. Res. 109: 185-94.

JHA A.K., PRASAD K., KULKARNI A.R., 2009 - Plant system: nature's nanofactory. - Colloids. Surf. B. Biointerf. 73: 219-223.

KALAIVANI K., SENTHIL-NATHAN S., MURUGESAN A.G., 2012 Biological activity of selected Lamiaceae and Zingiberaceae plant essential oils against the dengue vector Aedes aegypti L. (Diptera: Culicidae). - Parasitol. Res.110: 1261-1268.

KALIMUTHU K., PANNEERSELVAM C., MURUGAN K., HWANG J.-S., 2013 - Green synthesis of silver nanoparticles using Cadaba indica lam leaf extract and its larvicidal and pupicidal activity against Anopheles stephensi and Culex quinquefasciatus. - J. Entomol. Acarol. Res. 45: el1.

KARUNAMOORTHI K., SABESAN S., JEGAJEEVANRAM K., VIJAYALAKSHMI J., 2013 - Role of traditional antimalarial plants in the battle against the global malaria burden. - Vector-Borne. Zoon. Dis. 13: 521-544.

KASTHURI J., KATHIRAVAN K., RAJENDIRAN N., 2009 - Phyllanthinassisted biosynthesis of silver and gold nanoparticles: A novel biological approach. - J. Nanoparticle Res. 11: 1075-1085.

KEKWICK R.G.O., 2007 - Latex and laticifers - In: ROBERTS K. (Ed.), Handbook of plant science. John Wiley and Sons, UK: 1060-1074.

KHAN N., SULTANA S., 2005 - Chemomodulatory effect of Ficus racemosa extract against chemically induced renal carcinogenesis and oxidative damage response in wistar rats. - Life Sci. 77: 1194-1205.

KIM J.S., KUK E., YU K.N., KIM J.H., PARK S.J., LEE H.J., KIM S.H., PARK Y.K., PARK Y.H., HWANG C.Y., KIM Y.K., LEE Y.S., JEONG 
D.H., CHO M.H., 2007 - Antimicrobial effects of silver nanoparticles. - Nanomed. Nanotechnol. Biol. Med. 3: 95-101.

KOKATE A., 1999 - Phytochemical methods. - Phytotherapy 78: 126-129.

KUMAR S., MALHOTRA R., KUMAR D., 2002 - Euphorbia hirta: Its chemistry, traditional and medicinal uses, and pharmacological activities. - Phrmacogn. Rev. 4: 58-61.

LI R.W., LEACH D.N., MYERS S.P., LIN G.D., LEACH G.J., WATERMAN P.G.A., 2004 - New anti-inflammatory glucoside from Ficus racemosa L - Planta Med. 70: 421-426.

LIAU S.Y., READ D.C., PUGH W.J., FURR J.R., RUSSELL A.D., 1997 Interaction of silver nitrate with readily identifiable groups: relationship to the antibacterial action of silver ions. - Lett. Appl. Microbiol. 25: 279-283.

LOPES K.L.B., THADEO M., AZEVEDO A.A., SOARES A.A., MEIRA R.M.S.A., 2009 - Articulated laticifers of vegetative organs Mandevilla atroviolaceae (Apocynaceae, Apocynoideae). - Botany 87: 202-209.

MARIMUTHU S., RAHUMAN A.A., GOVINDASAMY R., THIRUNAVUKKARASU S., ARIVARASAN V.K., CHIDAMBARAM J., ASOKAN B., ZAHIR A.A., ELANGO G., CHINNAPERUMAL K., 2011 - Evaluation of green synthesized silver nanoparticles against parasites. - Parasitol. Res. 108: 1541-1549.

MORSY T.A., RAHEM M.A., ALLAM K.A., 2001 - Control of Musca domestica third instar larvae by the latex of Calotropis procera (Family: Asclepiadaceae). - J. Egyptian Soc. Parasitol. 31: 107-110.

MURUGAN K., MADHIYAZHAGAN P., NARESHKUMAR A., NATARAJ T., DINESH D., HWANG J.S., NICOLETTI M., 2012 - Mosquitocidal and water purification properties of Ocimum sanctum and Phyllanthus emblica. - J. Entomol. Acarolol. Res. 44: e17.

NVBDCP (NATIONAL VECTOR BOURNE DISEASE CONTROL PROGRAMME), 2011 - National vector bourne disease control programme, India. - Available form: http://nvbdcp.gov.in/malaria3.html Accessed: June 17, 2013.

PAREKH J., CHANDA V.S., 2007 - In vitro antimicrobial activity and phytochemical analysis of some Indian medicinal plants. - Turk. J. Biol. 31: 53-58.

PATIL C.D., BORASE H.P., PATIL S.V., SALUNKHE R.B., SALUNKE B.K., 2012a - Larvicidal activity of silver nanoparticles synthesized using Pergularia daemia plant latex against Aedes aegypti and Anopheles stephensi and nontarget fish Poecillia reticulata. - Parasitol. Res. 111: 555-562.

PATIL C.D., PATIL S.V., BORASE H.P., SALUNKE B.K., SALUNKHE R.B., 2011a - Larvicidal activity of silver nanoparticles synthesized using Plumeria rubra plant latex against Aedes aegypti and Anopheles stephensi. - Parasitol. Res. 110: 1815-1822.

PATIL C.D., PATIL S.V., SALUNKE B.K., SALUNKHE R.B., 2011b Bioefficacy of Plumbago zeylanica (Plumbaginaceae) and Cestrum nocturnum (Solanaceae) plant extracts against Aedes aegypti (Diptera: Culicide) and nontargetfish Poecilia reticulata. Parasitol. Res. 108: 1253-1263.

PATIL S.V., BORASE H.P., PATIL C.D., SALUNKE B.K., 2012b Biosynthesis of silver nanoparticles using latex from few euphorbian plants and their antimicrobial potential. - Appl. Biochem. Biotechnol. 167: 776-790.

RAGHVENDRA K., BARIK T.K., REDDY B.P.R., SHARMA P., DASH A.P., 2011 - Malaria vector control: from past to future. - Parasitol. Res. 108: 757-779.

RAHUMAN A.A., VENKATESAN P., GEETHA K., GOPALAKRISHNA G., 2008 - Mosquito larvicidal activity of gluanol acetate, a tetracyclictriterpenes derived from Ficus racemosa Linn. - Parasitol. Res. 103: 333-339.

RAJEH M.A.B., ZURAINI Z., SASIDHARAN S., LATHA L.Y., AMUTHA S., 2012 - Assessment of Euphorbia hirta L. leaf, flower, stem and root extracts for their antibacterial and antifungal activity and brine shrimp lethality. - Molecules. 15: 6008-6018.
RAMOS M.V., BANDEIRA G.P., FREITAS C.D.T., NOGUEIRA N.A.P., ALENCAR N.M.N., SOUSA P.A.S., CARVALHO A.F.F.U., 2006 - Latex constituents from Calotropis procera (Ait.) R.Br. display toxicity upon egg hatching and larvae of Aedes aegypti (Linn.). - Brazil Mem. Inst. Oswaldo. Cruz. 101: 503-510.

RAMOS M.V., FREITAS C.D.T., STANISÇUASKI F., MACEDO L.L.P., SALES M.P., SOUSA D.P., CARLINI C.R., 2007 - Performance of distinct crop pests reared on diets enriched with latex proteins from Calotropis procera: role of laticifier proteins in plant defense. Plant Sci. 173: 349-357.

RAMOS M.V., PEREIRA D.A., SOUZA D.P., ARAÚJO E.S., FREITAS C.D.T., CAVALHEIRO M.G., MATOS M.P.V., CARVALHO A.F.F.U., 2009 Potential of laticifer fluids for inhibiting Aedes aegypti larval development: evidence for the involvement of proteolytic activity. Brazil Mem. Inst. Oswaldo. Cruz. 104: 805-812.

SHAALAN E., CANYON DV., Faried M.W., ABDEL-WAHAB H., MANSOURA A., 2005 - A review of botanical phytochemicals with mosquitocidal potential. - Environ. Int. 31: 1149-1166.

SHANKAR S.S., RAI A., AHMAD A., SASTRY M., 2004 - Rapid synthesis of $\mathrm{Au}, \mathrm{Ag}$, and bimetallic $\mathrm{Au}$ core-Ag shell nanoparticles using Neem (Azadirachta indica) leaf broth. - J. Colloid. Interface. Sci. 275: 496-502.

SHARMA N., TRIVEDI P.C., 2002 - Screening of leaf extracts of some plants for their nematicidal and fungicidal properties against Meloidogyne incognita and Fusarium oxysporum. - Asian J. Exp. Sci. 16:21-28.

SINGH A.K., TALAT M., SINGH D.P., SRIVASTAV A., 2010 - Biosynthesis of gold and silver nanoparticles by natural precursor clove and their functionalization with amine group. - J. Nanoparticle. Res. 12: 1667-1675.

SMITHA S.L., NISSAMUDEEN K.M., PHILIP D., GOPCHANDRAN K.G., 2008 - Studies on surface plasmon resonance and photoluminescence of silver nanoparticles. - Spectrochim. Acta. 71: 186-190.

THAKUR M., PANDEY S., MEWADA A., SHAH R., OZA G., SHARON S., 2013 - Understanding the stability of silver nanoparticles bio-fabricated using Acacia arabica (Babool gum) and its hostile effect on microorganisms. - Spectrochim. Acta. 109: 344-347.

THIRUNAVUKKARASU S., RAHUMAN A.A., GOVINDASAMY R., MARIMUTHU S., ASOKAN B., CHIDAMBARAM J., ZAHIR A.A., ELANGO G., CHINNAPERUMAL K., 2010 - Synthesis of silver nanoparticles using Nelumbo nucifera leaf extract and its larvicidal activity against malaria and filariasis vectors. - Parasitol. Res. 108: 693-702.

VIGNESHWARAN N., KATHE A.A., VARADARAJAN P.V., NACHANE R.P., BALASUBRAMANYA R.H., 2006 - Biomimetics of silver nanoparticles by white rot fungus, Phaenerochaete chrysosporium. - Colloids. Surf. B. Biointerf. 53: 55-59.

WEI Q., LIAO Y., CHEN Y., WANG S.N., XU Y., TANG L., CHEN F., 2005 Isolation, characterisation and antifungal activity of beta-1, 3-glucanase from seeds of Jatropha curcas. - S. Afr. J. Bot. 71: 95-99.

WHO, 1996 - Report of the WHO informal consultation on the evaluation on the testing of insecticides. CTD/WHO PES/IC/96; 1:69. World Health Organization, Geneva.

WHO, 2009 - Dengue and severe dengue, Fact sheet No. 117. World Health Organization, Geneva. Available from: http//www.who.int/ mediacentre/factsheets/fs117/en/index.html Accessed: March 21, 2013.

WHO, 2011 - World Malaria Report 2011.- World Health Organization, Geneva. Available from: http://www.who.int/malaria/world_malaria_report_2011/en/ Accessed: June 01, 2013.

YADAV S.C., PANDE M., JAGANNADHAM M.V., 2006 - Highly stable glycosylated serine protease from the medicinal plant Euphorbia milii. - Phytochemistry 67: 1414-26.

YANG Y.C., LEE S.G., LEE H.K., KIM M.K., LEE S.H., 2002 - Apiperidine amide extracted from Piper longum L. fruit shows activity against Aedes aegypti mosquito larvae. - J. Agric. Food Chem. 50: 3765-3767. 